\title{
De Corona Check-app: monitoring en advies
}

Geert Elbers, Annet Sollie

\begin{abstract}
Met de Corona Check-app kunnen gebruikers die denken dat ze COVID-19 hebben advies krijgen op basis van de coronasymptomen die ze dagelijks invullen. De app geeft aan of de gebruiker waarschijnlijk wel of niet corona heeft en of deze al dan niet acute behandeling nodig heeft. Ook verwijst de app naar de juiste zorgverlener.
\end{abstract}

De Corona Check-app van appontwikkelaar Luscii is een voorbeeld van 'blended care'-gebruik van een medische app. De app is medisch vormgegeven door het OLVG en later aangevuld door een bredere inhoudelijke commissie van long- en huisartsen. Het initiatief om de app in te zetten ligt bij de gebruiker. Iedere Nederlander die zich zorgen maakt over het coronavirus kan deze app uit de appstore downloaden. Eerst moet een aantal gegevens worden ingevuld: leeftijd, postcode, vrouw/man, wel of geen afweeronderdrukkende medicatie, comorbiditeit en resultaten van een eventueel eerdere coronatest. Vervolgens kan de gebruiker via de app dagelijks scoren op een aantal symptomen (reuk- en smaakverlies, hoesten, keelpijn, neusverkoudheid, kortademigheid en temperatuur), op een schaal van 1 tot 10. Elke dag ontvangt de gebruiker hiervoor een herinneringsmail. Ook kan de gebruiker een verzoek tot terugbellen aangeven. Het medisch team beoordeelt of er contact nodig is. Dat gebeurt binnen 24 uur (ook in het weekend). Het medisch team bestaat uit coassistenten, gesuperviseerd door long- of huisartsen, verdeeld over 7 regio's in Nederland. Afhankelijk van de ingevulde waarden krijgt de gebruiker advies. Hij kan zijn eigen waarden over de ingevulde dagen terugzien in grafieken. De gegevens worden anoniem bewaard voor onderzoek. De app bevat ook extra algemene informatie over het coronavirus. Uitgebreide informatie over de eigenaren en de opzet van de app staat op www.decoronacheck.nl.

De Corona Check-app heeft een aantal voordelen. De app biedt dagelijkse monitoring van symptomen met daarbij een medisch advies op maat, zonder dat de werkdruk bij de huisarts oploopt. Er ligt meer regie bij de patiënt en als bijkomend voordeel is er ook nog dataverzameling per regio. Op Thuisarts.nl is overigens ook een goede digitale checklist te vinden (www.thuisarts.nl/vragentest/corona), maar deze geeft alleen digitaal advies.

Een nadeel van de app is de overname van een deel van de zorg die de huisarts anders misschien zou hebben geleverd, waardoor de huisarts zicht op de eigen patiënten zou kunnen verliezen. Verder kunnen er fout-positieve en fout-negatieve COVID-19-gevallen worden gedetecteerd door beslisregels die niet zijn gevalideerd. Een ander nadeel is het mogelijk missen van acute gevallen doordat een patiënt de app gebruikt als spoedzorgmiddel.

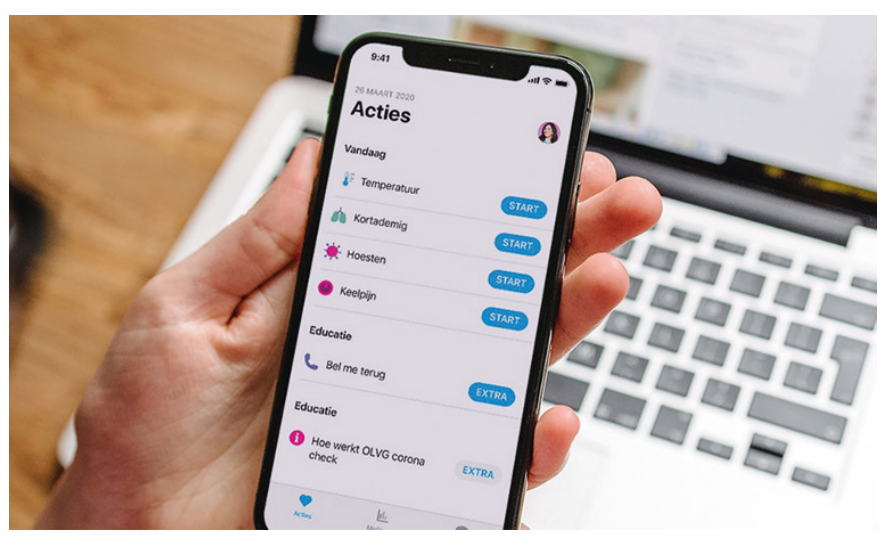

\section{CONCLUSIE}

De Corona Check-app kan op eigen initiatief of op advies van een arts worden gebruikt. De gebruiker vult dagelijks een checklist in van 5 klachten die zijn gerelateerd aan het coronavirus en krijgt passend digitaal advies. Als er waarden in het risicogebied vallen, beoordeelt een medisch team of telefonisch contact nodig is. De Corona Check-app: het lijkt tot nu toe een waardevolle en veilig app. -

Geert Elbers is betrokken bij de implementatie van de app in de regio Noord-Brabant en Zeeland en heeft in die hoedanigheid zitting in de medical board [inhoudelijke commissie]. Hij is op geen enkele wijze financieel bij de app betrokken.

Op moment van acceptatie voor publicatie [8 juni 2020] zijn er 165.323 actieve gebruikers die de app dagelijks invullen, is er 57.626 keer telefonisch contact geweest, is er 5180 keer de diagnose corona gesteld en zijn 2451 patiënten genezen verklaard.

\begin{tabular}{ll} 
Naam & De Corona Check \\
Maker & OLVG en Luscii \\
Doel & Bijhouden en checken coronasymptomen, advies geven \\
\hline Platform & iOS, Android, als app, aanmelden via website coronacheck.nl \\
\hline Prijs & Gratis \\
\hline Oordeel & $\bullet \bullet \bullet$
\end{tabular}

